\title{
Versatile vector suite for the extracytoplasmic production and purification of heterologous His-tagged proteins in Lactococcus lactis
}

\author{
Jolanda Neef ${ }^{1}$ - Fin J. Milder ${ }^{2}$ - Danny G. A. M. Koedijk ${ }^{1} \cdot$ Marindy Klaassens $^{1}$ • \\ Erik C. Heezius ${ }^{2}$ - Jos A. G. van Strijp ${ }^{2}$ - Andreas Otto ${ }^{3}$ • Dörte Becher ${ }^{3}$. \\ Jan Maarten van Dijl ${ }^{1}$ • Girbe Buist ${ }^{1}$ (D)
}

Received: 1 May 2015 /Revised: 5 June 2015 / Accepted: 17 June 2015 /Published online: 10 July 2015

(C) The Author(s) 2015. This article is published with open access at Springerlink.com

\begin{abstract}
Recent studies have shown that the Gram-positive bacterium Lactococcus lactis can be exploited for the expression of heterologous proteins; however, a versatile set of vectors suitable for inducible extracellular protein production and subsequent purification of the expressed proteins by immobilized metal affinity chromatography was so far lacking. Here we describe three novel vectors that, respectively, facilitate the nisin-inducible production of $\mathrm{N}$ - or C-terminally hexa-histidine $\left(\mathrm{His}_{6}\right)$-tagged proteins in L. lactis. One of these vectors also encodes a tobacco etch virus (TEV) protease cleavage site allowing removal of the N-terminal $\mathrm{His}_{6}$-tag from expressed proteins. Successful application of the developed vectors for protein expression, purification and/or functional studies is exemplified with six different cell wall-bound or secreted proteins from Staphylococcus aureus. The results show that secretory production of $S$. aureus proteins is affected by the position, $\mathrm{N}$ - or C-terminal, of the $\mathrm{His}_{6}$-tag. This seems to be due to an influence of the $\mathrm{His}_{6}$-tag on protein
\end{abstract}

Electronic supplementary material The online version of this article (doi:10.1007/s00253-015-6778-8) contains supplementary material, which is available to authorized users.

Girbe Buist

g.buist@umcg.nl

1 Department of Medical Microbiology, University of Groningen, University Medical Center Groningen, Hanzeplein 1, P.O. Box 30001, 9700 RB Groningen, The Netherlands

2 Department of Medical Microbiology, University Medical Center Utrecht, PO G04.614, Heidelberglaan 100, 3584 CX Utrecht, The Netherlands

3 Institut für Mikrobiologie, Ernst-Moritz-Arndt Universität Greifswald, Friedrich-Ludwig-Jahn-Str. 15, D-17489 Greifswald, Germany stability. Intriguingly, the $S$. aureus IsdB protein, which is phosphorylated in S. aureus, was also found to be phosphorylated when heterologously produced in L. lactis, albeit not on the same Tyr residue. This implies that this particular posttranslational protein modification is to some extent conserved in $S$. aureus and L. lactis. Altogether, we are confident that the present vector set combined with the L. lactis expression host has the potential to become a very useful tool in optimization of the expression, purification and functional analysis of extracytoplasmic bacterial proteins.

Keywords L. lactis · Expression vectors · NICE · Usp45 · Histidine tag $\cdot$ Secretion

\section{Introduction}

Over the past decades, a wide range of bacterial expression systems for heterologous protein production has been developed (Zerbs et al. 2009). Today, the Gram-negative bacterium Escherichia coli is one of the most commonly used organisms for large-scale heterologous protein production (Terpe 2006). This is due to the ease of handling, the multitude of available expression vectors and the relatively simple fermentation procedures for E. coli (Zerbs et al. 2009; Chen 2012). Despite these advantages, some clear disadvantages of the use of $E$. coli are evident. In the first place, E. coli is not capable of efficiently secreting heterologous proteins into the growth medium since exported proteins usually remain confined in the periplasm. Secondly, overexpression of heterologous proteins in $E$. coli often leads to the formation of high-density aggregates of misfolded proteins known as inclusion bodies. Thirdly, the post-translational modification of proteins that are heterologously produced in $E$. coli is likely to be different 
from the modification that these proteins undergo in their original host. Lastly, the inherent production of the wellknown endotoxin lipopolysaccharide (LPS) is a major drawback for the clinical application of $E$. coli-derived recombinant proteins (Braun et al. 1999; Petsch and Anspach 2000; Sarvas et al. 2004; Westers et al. 2004; Neef et al. 2014).

While $E$. coli has become a preferred host for the cytoplasmic production of structurally simple biotherapeutics, other bacterial species, especially Gram-positive bacteria, are preferred hosts for the secretory production of structurally more challenging types of proteins. For example, Bacillus species are highly popular expression platforms for enzymes (Terpe 2006). Importantly, organisms such as Bacillus subtilis are generally regarded as safe (GRAS). Moreover, they can secrete proteins directly into the fermentation broth to high concentrations, thereby simplifying their downstream processing. However, bacilli often secrete endogenous proteases at high levels, which often requires the use of multiple proteasedeficient strains (Li et al. 2004; Krishnappa et al. 2013). Alternatively, the Gram-positive bacterium Lactococcus lactis has been successfully applied for the secretory production of protease-sensitive proteins (Morello et al. 2008; Neef et al. 2014). This relates to the fact that this GRAS organism produces only two proteases that can potentially interfere with protein production. These two proteases, the cytoplasmic ClpP protease and the extracytoplasmic HtrA protease, are completely dispensable and their removal strongly reduces product degradation (Morello et al. 2008; Poquet et al. 2000; Miyoshi et al. 2002; Cortes-Perez et al. 2006). Moreover, the unwanted autolysis of L. lactis cells is prevented by the removal of the major autolysin AcmA which, combined with an $h$ trA deletion, leads to the stable and efficient production of secreted proteinaceous antigens of Staphylococcus aureus (Neef et al. 2014).

Several inducible expression systems have been developed for L. lactis (Morello et al. 2008) of which the nisin-inducible (NICE) system is the most efficient and extensively used (Mierau 2005). This system is based on the regulation of the nis $A$ promoter by the food-grade lantibiotic nisin, which activates the NisRK two-component regulatory system (De Ruyter et al. 1996). The NICE system has thus been used for production of a wide range of homologous and heterologous proteins, including vaccines (Zhou et al. 2006).

The purification of overproduced proteins can be facilitated by particular tags that bind with high affinity to a specific matrix. The hexa-histidine ( His $\left._{6}\right)$-tag is the most widely used tag and ensures efficient separation by metal affinity chromatography (Jones et al. 1995). However, the exact placement of these tags can influence the solubility and/or stability of overproduced proteins (Woestenenk et al. 2004). To circumvent the latter problems, changing the location of the $\mathrm{His}_{6}$-tag from the $\mathrm{N}$ - to the $\mathrm{C}$-terminus or vice versa may prove beneficial. Notably, although the $\mathrm{His}_{6}$-tag has usually limited impact on protein structure or function (Terpe 2003), it is desirable to remove it prior to structure-function studies (Arnau et al. 2011). Therefore, a specific protease cleavage site, e.g. for the tobacco etch virus (TEV) protease, is often placed between the target protein and the affinity tag.

In this study, we describe an expression vector set that facilitates convenient exploration of nisin-inducible protein production in L. lactis. As shown with a representative panel of extracytoplasmic proteinaceous antigens from $S$. aureus, the overproduced proteins can be purified by metal affinity chromatography using $\mathrm{N}$ - or $\mathrm{C}$-terminal $\mathrm{His}_{6}$-tags. The latter is useful since our present results show that, also in L. lactis, the exact position of the $\mathrm{His}_{6}$-tag affects production efficiency and/or protein stability. In one vector configuration, the $\mathrm{His}_{6}{ }^{-}$ tag can be removed from the expressed proteins by cleavage with the TEV protease. Of note, we show that L. lactis is capable of phosphorylating the IsdB protein of $S$. aureus.

\section{Materials and methods}

\section{Bacterial strains and growth conditions}

Strains and plasmids are listed in Table 1. E. coli was grown at $37{ }^{\circ} \mathrm{C}$ in Lysogeny broth (LB; Becton Dickinson, Breda, The Netherlands) with ampicillin $(100 \mu \mathrm{g} / \mathrm{ml})$ for plasmid selection. L. lactis was grown at $30{ }^{\circ} \mathrm{C}$ in M17 broth (Oxoid Limited, Hampshire, UK) supplemented with $0.5 \%$ glucose $(w / v)$ (GM17). Chloramphenicol $(5 \mu \mathrm{g} / \mathrm{ml})$ was added when needed. For nisin production, the L. lactis NZ9700 strain was cultured in GM17 and the cell-free supernatant was used for induction of the $\mathrm{P}_{\text {nisA }}$ promoter in a 1:1000 dilution at $\mathrm{OD}_{600} \sim$ 0.5 (Kuipers et al. 1997).

\section{General molecular biology}

Enzymes and buffers were from New England Biolabs (Ipswich, UK) and Fermentas (Landsmeer, The Netherlands). PCR was performed using a Bio-Rad C1000 Thermal Cycler (Richmond, CA). Primers were from Eurogentec (Maastricht, The Netherlands) (Table 2 and Table S1). The polymerases PFU (Fermentas, Landsmeer, The Netherlands), Pwo (Roche, Woerden, The Netherlands) and Taq (Life Technologies, Bleiswijk, The Netherlands) were used according to the manufacturer. PCR products were purified using the High Pure PCR Purification Kit from Roche (Woerden, The Netherlands). Plasmid purification was performed using the Plasmid Isolation Kit from Analytik Jena AG (Jena, Germany); L. lactis was lysed by incubation with lysozyme $(4 \mathrm{mg} / \mathrm{ml}$; Sigma-Aldrich, Zwijndrecht, The Netherlands) for $10 \mathrm{~min}$ at $55{ }^{\circ} \mathrm{C}$ in resuspension buffer followed by addition of lysis buffer. L. lactis was transformed by electroporation using a Gene Pulser (Biorad; Leenhouts 
Table 1 Bacterial strains and plasmids used in this study

\begin{tabular}{|c|c|c|}
\hline Strain or plasmid & Relevant phenotype(s) or genotype(s) & Source and reference \\
\hline \multicolumn{3}{|l|}{ Strains } \\
\hline L. lactis NZ9700 & Nisin producer & $\begin{array}{l}\text { NIZO culture collection, Ede, } \\
\text { The Netherlands } \\
\text { (Kuipers et al. 1993) }\end{array}$ \\
\hline L. lactis PA1001 & $\begin{array}{l}\text { MG1363 pep } N:: \text { his } R K \text {, allows nisin-inducible } \\
\text { expression, } \triangle \text { acmA } \Delta \text { htrA }\end{array}$ & $\begin{array}{l}\text { Mucosis culture collection, Groningen, } \\
\text { The Netherlands } \\
\text { (Bosma et al. 2006) }\end{array}$ \\
\hline S. aureus Newman & NCTC 8178 clinical isolate & $\begin{array}{l}\text { PHE culture collection NCTC } 8178 \\
\text { (Duthie and Lorenz 1952) }\end{array}$ \\
\hline S. aureus USA300 & Community-acquired MRSA isolate & $\begin{array}{l}\text { ATCC strain BAA-1717 } \\
\text { (McDougal et al. 2003) }\end{array}$ \\
\hline S. aureus N315 & Hospital-acquired MRSA & (Kuroda et al. 2001) \\
\hline S. aureus NCTC 8325 & $\begin{array}{l}\text { Restriction-deficient derivative of NCTC } 8325 \text {; } \\
\text { cured of all known prophages }\end{array}$ & $\begin{array}{l}\text { WDCM culture collection } 154 \\
\text { (Kreiswirth et al. 1983) }\end{array}$ \\
\hline \multicolumn{3}{|l|}{ Plasmids } \\
\hline $\mathrm{pET302/NT}$ & $\mathrm{Ap}^{\mathrm{R}}$, containing $\mathrm{P}_{\mathrm{T} 7}$, lacO, MCS, his 6 , $\mathrm{T} 7$ terminator & Life Technologies \\
\hline pEF110 & $\begin{array}{l}\mathrm{pET} 302 / \mathrm{NT} \text { derivative, } \mathrm{Ap}^{\mathrm{R}} \text {, containing } \mathrm{P}_{\mathrm{T} 7}, \text { his }_{6} \\
\text { Bam } \mathrm{HI} / \text { EcoRI-XbaI/Not } \mathrm{I} \text { cloning sites }\end{array}$ & Laboratory collection J.A.G. van Strijp \\
\hline pEF111 & $\begin{array}{l}\mathrm{pET} 302 / \mathrm{NT} \text { derivative, Ap }{ }^{\mathrm{R}} \text {, containing } \mathrm{P}_{\mathrm{T}}, \text { his }_{6}, \\
\text { TEV cleavage site, } \text { Bam HI/EcoRI-XbaI/Not cloning sites }\end{array}$ & Laboratory collection J.A.G. van Strijp \\
\hline pEF210 & $\begin{array}{l}\text { pET302/NT derivative, } \text { Ap }^{\mathrm{R}} \text {, containing } \mathrm{P}_{\mathrm{T} 7} \\
\text { Bam } \mathrm{HI} / \text { EcoRI-XbaI/Not } \mathrm{I} \text { cloning sites, } \text { his }_{6}\end{array}$ & Laboratory collection J.A.G. van Strijp \\
\hline pNG400 & $\mathrm{Cm}^{\mathrm{R}}$, containing $\mathrm{P}_{n i s A}, \mathrm{SS}_{u s p 45}$, and a transcription terminator & (Bosma et al. 2006) \\
\hline pNG4110 & $\begin{array}{l}\text { pNG400 derivative, containing } h i s_{6} \\
\text { Bam } \mathrm{HI} / E c o \text { RI-XbaI/NotI cloning sites }\end{array}$ & This study \\
\hline pNG4111 & $\begin{array}{l}\text { pNG400 derivative, containing } h i s_{6}, \text { TEV cleavage site, } \\
\text { BamHI/EcoRI-XbaI/NotI cloning sites }\end{array}$ & This study \\
\hline pNG4210 & $\begin{array}{l}\text { pNG400 derivative, containing BamHI/EcoRI-XbaI/NotI } \\
\text { cloning sites, } h i_{6} \text { followed by a Stop codon }\end{array}$ & This study \\
\hline
\end{tabular}

$A p^{R}$ ampicillin resistance gene, $C m^{R}$ chloramphenicol resistance gene, $P_{T 7}$ IPTG inducible T7-promoter, $P_{\text {nis } A}$ nisin-inducible promoter, $h i_{6} 6$ histidine tag, $S S_{u s p 45}$ signal sequence of $u s p 45, M C S$ multiple cloning site

and Venema 1993). Nucleotide sequence analysis was performed by Eurofins DNA (Ebersberg, Germany).

\section{Construction of expression vectors}

The $E$. coli $\mathrm{pEF}$ vector set is based on plasmid $\mathrm{pET} 302 / \mathrm{NT}$. A total of three primer pairs were created (NHis_F/NHis_R for pEF110, CHis_F/CHis_R for pEF210, NHisTEV_F/ NHisTEV_R for pEF111) (Table 2) containing an NdeI and $B g l I I$ overhang at their $5^{\prime}$ and $3^{\prime}$ ends. These primers were annealed by incubation at a $1: 1$ ratio at $94{ }^{\circ} \mathrm{C}$ and stepwisecontrolled temperature drops to room temperature. The fragments were ligated into the $N d e \mathrm{I}$ and BamHI digested $\mathrm{pET} 302 / \mathrm{NT}$ vector resulting in deletion of the original vector-derived $\mathrm{BamHI}$ site and introduction of a multiple cloning site comprising BamHI, EcoRI, XhoI and NotI restriction sites (Fig. 1). Following transformation in E. coli TOP10F cells, the prepared constructs were sequence-verified.

L. lactis vectors were constructed based on the $\mathrm{pEF}$ vectors by amplifying the multiple cloning site together with the $\mathrm{His}_{6}{ }^{-}$ tag and the TEV cleavage site (encoded by the specific amino acid sequence EQLYFOG (Arnau et al. 2011) using the primers in Table 2. For construction of pNG4110 and pNG4111, the primer combinations pEF110.fw/pEF110.rev and $\mathrm{pEF} 111$.fw/pEF111.rev were used with plasmids pEF110 and pEF111 as templates, respectively. PCR products were digested using HindIII and BsmBI resulting in HindIII and $N c o$ I overhangs and ligated into plasmid pNG400 digested with HindIII and NcoI. For the construction of pNG4210, primers $\mathrm{pEF} 210 . \mathrm{fw} / \mathrm{pEF} 210$.rev were used with plasmid pEF210 as template DNA. The PCR products and receiving plasmid pNG400 were digested using $\mathrm{NcoI}$ and HindIII. After ligation, the resulting vectors were used to transform L. lactis PA1001. For expression of extracellular proteins of $S$. aureus in L. lactis, the respective genes were amplified by PCR with Pwo polymerase from chromosomal DNA of $S$. aureus strains USA300 or NCTC8325 (see Table 3). Genes amplified with the $\mathrm{f} 1 / \mathrm{r} 2$ primer sets were cloned in pNG4110 and pNG4111, and genes amplified with the $\mathrm{fl} / \mathrm{r} 1$ primer sets in pNG4210 using the BamHI/Not I 
Table 2 Primers used for the construction of the expression vectors

\begin{tabular}{|c|c|c|}
\hline Primer & $5^{\prime} \rightarrow 3^{\prime}$ nucleotide sequence ${ }^{a}$ & Restriction site ${ }^{\mathrm{b}}$ \\
\hline NHis_F & TATGCACCATCACCATCACCATGGATCCGAATTCCTCGAGGCGGCCGCATAAA & \\
\hline NHis_R & ACGTGGTAGTGGTAGTGGTACCTAGGCTTAAGGAGCTCCGCCGGCGTATTTCTAG & \\
\hline CHis_F & TATGGGATCCGAATTCCTCGAGGCGGCCGCACACCATCACCATCACCATTAAA & \\
\hline CHis_R & ACCCTAGGCTTAAGGAGCTCCGCCGGCGTGTGGTAGTGGTAGTGGTAATTTCTAG & \\
\hline NHisTEV_F & $\begin{array}{l}\text { TATGCACCATCACCATCACCATGAGAACCTGTACTTCCAGGGAT } \\
\text { CCGAATTCCTCGAGGCGGCCGCATAAA }\end{array}$ & \\
\hline NHisTEV_R & $\begin{array}{l}\text { ACGTGGTAGTGGTAGTGGTACTCTTGGACATGAAGGTCCCTAGG } \\
\text { CTTAAGGAGCTCCGCCGGCGTATTTCTAG }\end{array}$ & \\
\hline pEF110.f & CCCCGTCTCCCATGCACCATCACCATCATCATGGATCCGAA & BsmBI \\
\hline pEF110.r & CCCAAGCTTTTACCATGGTGCGGCCGCCTCGAGG & HindIII and NotI \\
\hline pEF111.f & CCCCGTCTCCCATGCACCATCACCATCACCATGAG & BsmBI \\
\hline pEF111.r & CCCAAGCTTTTATGCGGCCGCCTCGAGG & HindIII \\
\hline pEF210.f & CCCСCATGGGATCCGAATTCCTCGAGGC & NcoI \\
\hline pEF210.r & CCCAAGCTTTTAATGGTGATGGTGATGGTGTGC & HindIII \\
\hline
\end{tabular}

${ }^{a}$ Restriction site underlined, stop codon in bold

${ }^{\mathrm{b}} B s m \mathrm{BI}$ restriction resulting in $N c o$ I overhang in italic

restriction sites (Table S1). Ligation mixtures were introduced into L. lactis PA1001. The resulting vectors were sequenceverified.

\section{Lithium dodecyl sulphate-polyacrylamide gel electrophoresis and Western blotting}

For lithium dodecyl sulphate-polyacrylamide gel electrophoresis (LDS-PAGE), cells were resuspended in LDS buffer (Life Technologies) and disrupted by bead beating with $0.1 \mu \mathrm{m}$ glass beads (Biospec Products, Bartlesville, USA) using a Precellys24 (Bertin Technologies, Montigny-leBretonneux, France), while secreted proteins in the culture medium were precipitated with $10 \%$ trichloroacetic acid (TCA). Protein samples were incubated for $10 \mathrm{~min}$ at $95^{\circ} \mathrm{C}$, separated by LDS-PAGE using $10 \%$ NuPAGE gels (Invitrogen) and stained with SimplyBlue ${ }^{\mathrm{TM}}$ SafeStain (Life Technologies). For Western blotting, proteins were transferred to a nitrocellulose membrane (Protran ${ }^{\circledR}$, Schleicher \& Schuell,
Dassel, Germany). Immunodetection was performed using anti-His-tag antibodies (Life Technologies). Bound antibodies were visualized using fluorescently labeled secondary antibodies (IRDye $800 \mathrm{CW}$ from LiCor Biosciences, NE, USA). Membranes were scanned for fluorescence at $800 \mathrm{~nm}$ using the Odyssey Infrared Imaging System (LiCor Biosciences).

\section{Protein production and isolation}

Overnight cultures of L. lactis were diluted 1:20 in GM17 medium containing chloramphenicol. Induction of $\mathrm{P}_{\text {nisA }}$ with nisin was performed for $16 \mathrm{~h}$. Cells producing $S$. aureus protein SA0620 were resuspended in binding buffer $(20 \mathrm{mM}$ sodium phosphate, $\mathrm{pH} 7.4,0.5 \mathrm{mM} \mathrm{NaCl}, 50 \mathrm{mM}$ imidazole) and disrupted by bead beating. The S. aureus proteins SA2100 and pro-Atl were precipitated from the growth medium of L. lactis with $10 \%$ TCA. The SA0620 protein in cell-free extracts and the TCA-precipitated SA2 100 and pro-Atl proteins were purified by metal affinity chromatography with His

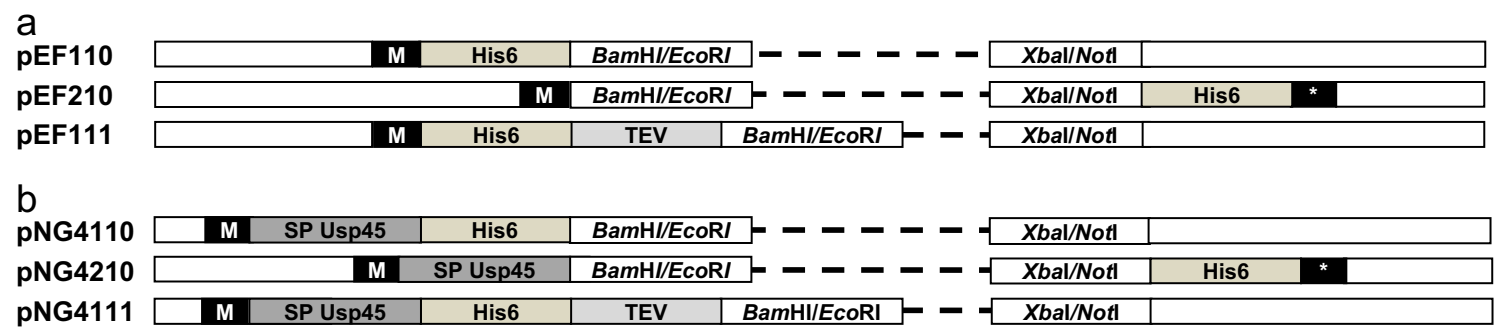

Fig. 1 Expression cassettes present in the vectors for heterologous protein production in E. coli or L. lactis. a Expression cassettes of the E. coli $\mathrm{pEF}$ vectors, encoding an $\mathrm{N}$-terminal $\mathrm{His}_{6}$-tag (pEF110), a Cterminal His $_{6}$-tag (pEF210) or a TEV-removable (TEV) N-terminal $\mathrm{His}_{6}$-tag (pEF111). Restriction sites for cloning (BamHI/EcoRI or XbaI/ NotI, respectively), start codons $(\mathrm{M})$ and stop codons $(*)$ are indicated. b
Expression cassettes of the L. lactis $\mathrm{pNG}$ vectors, encoding an N-terminal His $_{6}$-tag (pNG4110), a C-terminal His ${ }_{6}$-tag $\left(\mathrm{pNG}^{2}\right.$ 210) or a TEVremovable (TEV) N-terminal His ${ }_{6}$-tag (pNG4111). Restriction sites for cloning (BamHI/EcoRI or XbaI/NotI, respectively), start codons (M), the Usp 45 signal sequence (SP Usp45) and stop codons (*) are indicated 
Table 3 S. aureus proteins used in this study

\begin{tabular}{|c|c|c|c|c|c|}
\hline Name and function & $\mathrm{NCBI}^{\mathrm{a}}$ & $\mathrm{Aa}^{\mathrm{b}}$ & $\mathrm{pI}^{\mathrm{c}}$ & $\mathrm{kDa}^{\mathrm{d}}$ & Constructs \\
\hline \multirow{3}{*}{$\begin{array}{l}\text { SA0620, Secretory antigen } \\
\text { SsaA homologue (ssaA like) }\end{array}$} & \multirow[t]{3}{*}{ USA300HOU_0686 } & \multirow[t]{3}{*}{$26-265$} & 6.44 & 27.2 & pNG4110-sa0620 \\
\hline & & & 6.26 & 28.0 & pNG4111-sa0620 \\
\hline & & & 6.44 & 27.1 & pNG4210-sa0620 \\
\hline \multirow[t]{3}{*}{ FtsL, cell division } & \multirow[t]{3}{*}{ USA300HOU_1120 } & \multirow[t]{3}{*}{$66-133$} & 9.41 & 8.9 & pNG4110-ftsL \\
\hline & & & 9.02 & 9.7 & pNG4111-ftsL \\
\hline & & & 9.41 & 9.1 & pNG4210-ftsL \\
\hline \multirow[t]{3}{*}{ ClfB, clumping factor B } & \multirow[t]{3}{*}{ USA300HOU_2630 } & \multirow[t]{3}{*}{$45-567$} & 4.68 & 57.8 & pNG4110-clfB \\
\hline & & & 4.65 & 58.6 & pNG4111-clfB \\
\hline & & & 4.68 & 57.9 & pNG4210-clfB \\
\hline \multirow[t]{3}{*}{ Hypothetical protein SA2100, similar to autolysin E } & \multirow[t]{3}{*}{ USA300HOU_2288 } & \multirow[t]{3}{*}{$27-258$} & 8.95 & 27.7 & pNG4110-sa2100 \\
\hline & & & 8.62 & 28.5 & pNG4111-sa2100 \\
\hline & & & 8.95 & 27.9 & pNG4210-sa2100 \\
\hline \multirow[t]{3}{*}{ Pro-Atl, pro-peptide autolysin Atl } & \multirow[t]{3}{*}{ SAOUHSC_00994 } & \multirow[t]{3}{*}{$29-199$} & 9.02 & 19.0 & pNG4110-pro-atl \\
\hline & & & 7.87 & 19.8 & pNG4111-pro-atl \\
\hline & & & 9.02 & 18.9 & pNG4210-pro-atl \\
\hline \multirow[t]{3}{*}{ IsdB, iron-regulated heme-iron binding protein } & & \multirow[t]{3}{*}{$41-609$} & 9.18 & 64.9 & pNG4110-isdB \\
\hline & & & 9.10 & 65.7 & pNG4111-isdB \\
\hline & & & 9.18 & 65.2 & pNG4210-isdB \\
\hline
\end{tabular}

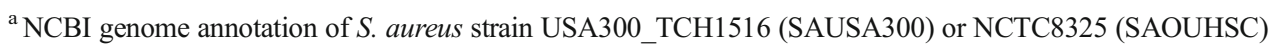

${ }^{\mathrm{b}}$ Numbers of first and last amino acid residues of the proteins expressed in L. lactis

${ }^{\mathrm{c}}$ Isoelectric point

${ }^{\mathrm{d}}$ Molecular weight

Mag SepharoseTM Ni beads (Mag beads; GE Healthcare, Little Chalfont, UK). Incubation with Mag beads was performed for $\sim 1 \mathrm{~h}$ at room temperature; unbound proteins were removed by washing with binding buffer, and bound proteins were eluted with elution buffer $(20 \mathrm{mM}$ sodium phosphate, $\mathrm{pH} 7.4,0.5 \mathrm{M} \mathrm{NaCl}$ and $500 \mathrm{mM}$ imidazole).

\section{Protein activity assays}

To analyse the possibility of the TEV cleavage, L. lactis culture medium containing His $_{6}$-TEV-FtsL, was dialysed against phosphate buffered saline (PBS) and incubated $16 \mathrm{~h}$ at $4{ }^{\circ} \mathrm{C}$ with $10 \mathrm{U}$ TurboTEV protease (Eton Bioscience, Inc., San Diego, CA). Proteins were separated on a $10 \%$ NuPAGE gel and stained with SimplyBlue.

Cell wall hydrolase activity of $\mathrm{His}_{6}$-tagged derivatives of the SA2100 protein was analysed in zymograms using sodium dodecyl sulfate-polyacrylamide (SDS-PAA) gels (12.5\%) containing $0.15 \%$ autoclaved, lyophilized Micrococcus lysodeikticus ATCC 4698 cells (Sigma-Aldrich.), as described (Buist et al. 1997).

Clumping activity of ClfB was analysed by growing induced PA1001 cells expressing $c l f B$ in a 12-well microtitre plate. After overnight induction with nisin, the plate was gently stirred. Cell clumping was visualized using a G-Box Chemi XT16 (Syngene, Cambridge, UK).

\section{Analysis of phosphorylation}

Phosphorylation of $\mathrm{His}_{6}$-IsdB and $\mathrm{His}_{6}$-TEV-IsdB was visualized by LDS-PAGE and subsequent staining with Pro-Q ${ }^{\circledR}$ Diamond phosphoprotein gel stain (Life Technologies). Cytosolic cell fractions were produced by bead beating of overnight nisin-induced cells. Cell debris was removed by centrifugation. Prior to separation by LDS-PAGE, cytosolic and secreted proteins were delipidated and desalted according to the instructions for use of the Pro-Q stain. Protein staining was visualized with the G-Box.

Gel pieces containing putatively phosphorylated proteins were prepared for mass spectrometric (MS) analysis as described (Bonn et al. 2014). Peptides were eluted and subjected to high-resolution and high mass accuracy MS measurements on an Orbitrap Elite coupled online to a Proxeon EASY-nLC 1000. The Orbitrap Elite was operated in data-dependent MS/ MS mode at a resolution of $R=60,000$ in the MS1 with the lockmass option enabled. Data-dependent triggering of fragment scans was set on the 20 most intense precursor ions. Multistage activation (MSA) was used for enhanced fragmentation of putative phosphate group containing ions as 
described (Basell et al. 2014). MS/MS spectra were searched against a target-decoy database including all protein sequences of $S$. aureus USA300 extracted from the UniProt database in addition to common laboratory contaminants and an appended set of the reversed sequences. Database searching was performed by Sequest (Thermo Fisher Scientific, San Jose, CA, USA; version v.27, rev. 11). Peptide hits were filtered with Scaffold (version Scaffold_4.3.4, Proteome Software Inc., Portland, OR). Mass tolerance for peptide identification on MS and MS/MS peaks were $10 \mathrm{ppm}$ and $1 \mathrm{Da}$, respectively. Up to two missed tryptic cleavages were allowed. Methionine oxidation and cysteine carbamidomethylation, as well as phosphorylation at serine, threonine or tyrosine, were set as variable modifications. Peptide identifications were accepted if they matched the following criteria: deltaCn scores of greater than 0.10 and XCorr scores of greater than, 2.5, 3.5 and 3.5 for doubly, triply and quadruply charged peptides. Protein identifications were accepted if they contained at least two identified peptides. Proteins that contained similar peptides and could not be differentiated based on MS/MS analysis alone were grouped to satisfy the principles of parsimony.

\section{Results}

\section{Development of a pNG vector set for heterologous protein production in $L$. lactis}

In previous studies, the $\mathrm{pEF}$ vector set was successfully used for heterologous protein expression in E. coli (Bardoel et al. 2012; Pel et al. 2014). This vector set offered convenient possibilities for $\mathrm{N}$ - or $\mathrm{C}$-terminal $\mathrm{His}_{6}$-tagging of expressed proteins (pEF110 and pEF210, respectively) and for TEVmediated tag removal (pEF111; Fig. 1a). We therefore implemented the respective cloning sites, $\mathrm{His}_{6}$-tag sequences and TEV cleavage site sequence in the $\mathrm{pNG}$ series of L. lactis expression vectors. In addition, the $\mathrm{pNG}$ vectors were provided with the nisA promoter and the signal sequence of Usp45 for nisin-inducible secretory protein production. Specifically, this resulted in pNG4110 for expression of N-terminally $\mathrm{His}_{6}$ tagged proteins, pNG4210 for expression of C-terminally His $_{6}$-tagged proteins and pNG4111 for expression of proteins with a TEV protease-removable N-terminal His $_{6}$-tag (Fig. 1b).

The versatility of the pNG vectors was tested by expressing six different extracytoplasmic proteins of $S$. aureus. Notably, these included a secreted protein (SA0620), a membraneassociated protein (FtsL), two covalently cell wall-bound proteins (ClfB and IsdB), a non-covalently cell wall-bound protein (SA2100) and the pro-peptide of the major autolysin Atl (Table 2). To express these proteins, the L. lactis strain PA1001 was used, which has an improved stability due to a deletion of the $a \mathrm{~cm} A$ gene and a reduced proteolytic activity due to deletion of the htrA gene (Neef et al. 2014).

\section{Position of the $\mathrm{His}_{6}$-tagging affects SA0620 production in L. lactis}

In a previous study, we observed that the secretory antigen SsaA homologue SA0620 was not produced in L. lactis PA1001 when expressed with a C-terminal His $_{6}$-tag from plasmid pNG400 (Neef et al. 2014). To test whether this might be due to the location of the $\mathrm{His}_{6}$-tag, the gene for SA0620 was cloned in plasmids pNG4110, pNG4111 and pNG4210. After overnight induction with nisin, the expression of the resulting His $_{6}$-tagged proteins was analysed by LDS-PAGE and Western blotting. This showed that effective expression of the full-length SA0620 precursor and mature proteins (30.4 and $27.7 \mathrm{kDa}$, respectively) was only achieved when this protein was synthesized with an $\mathrm{N}$-terminal $\mathrm{His}_{6}$-tag as provided by pNG4110 (Fig. 2a). Precursor forms of SA0620 were observed in low amounts when expressed from pNG4111 or pNG4210, and in the latter case, also a degradation product of approximately $17 \mathrm{kDa}$ was detectable (Fig. 2a). For the $\mathrm{His}_{6}$-TEV-SA0620 variant produced from pNG4111, not even a degradation product was detectable. Notably, despite the fusion of SA0620 to the signal peptide of Usp45, no SA0620 or fragments thereof were detectable in the growth medium (Fig. 2a). Nevertheless, the expression in pNG4110 did allow purification of the mature SA0620 protein and a degradation product from cells disrupted by bead beating and subsequent treatment with $6 \mathrm{M}$ urea, as illustrated in Fig. 2b. Together, these data show that the N-terminal location of the $\mathrm{His}_{6}$-tag is critical for successful production and subsequent isolation of the full-length S. aureus antigen SA0620.

\section{TEV protease-mediated $\mathrm{His}_{6}$-tag removal from the secreted $\mathrm{His}_{6}$-TEV-FtsL protein}

To determine whether the $\mathrm{His}_{6}$-tag can proteolytically be removed from proteins expressed from the pNG4111 vector, by means of the encoded TEV cleavage site, the $S$. aureus cell division membrane protein FtsL was used. Specifically, the ftsL gene was expressed lacking the transmembrane helix. After induction with nisin, the $\mathrm{His}_{6}$-TEV-FtsL fusion protein was efficiently secreted into the culture medium of L. lactis (Fig. 3). Upon removal of cells by centrifugation, dialysis against PBS and incubation with the TurboTEV protease, cleavage of His $_{6}$-TEV-FtsL was analysed by LDS-PAGE and SimplyBlue staining. In the samples incubated in the absence of TurboTEV protease, the presumably complete fusion protein was detectable upon LDS-PAGE and SimplyBlue staining (Fig. 3). Of note, the apparent molecular weight $(\mathrm{Mw})$ of the fusion protein judged by its mobility on LDSPAGE was $\sim 12 \mathrm{kDa}$, while the predicted $\mathrm{Mw}$ is only $9.5 \mathrm{kDa}$. 

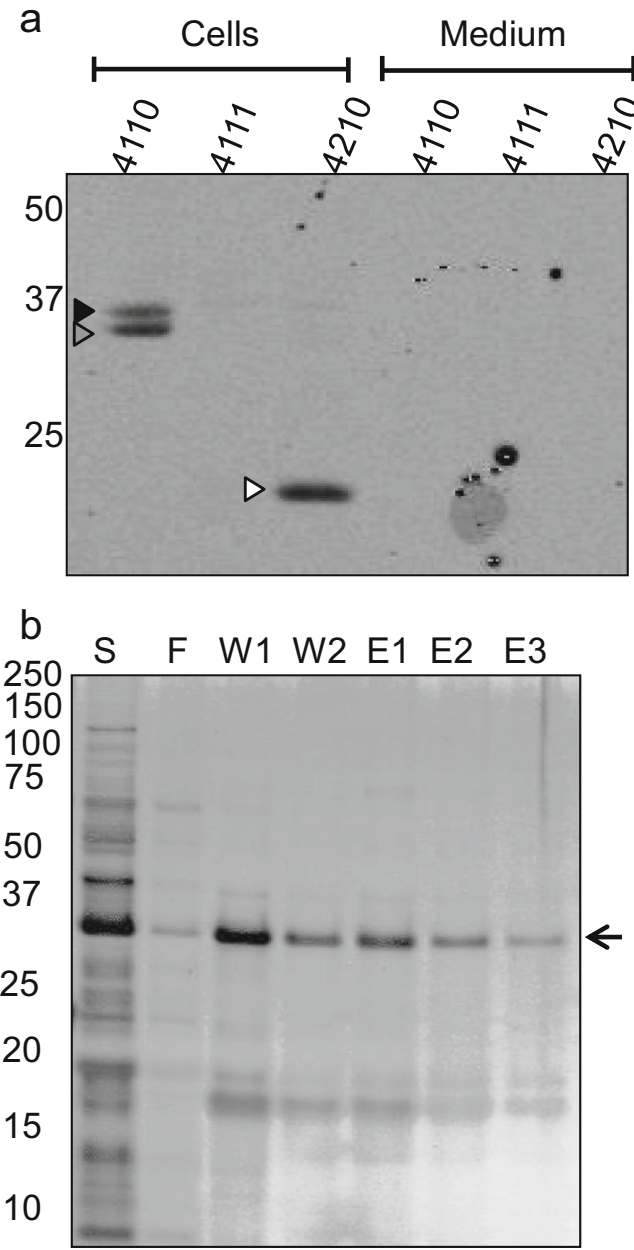

Fig. 2 Production and purification of the $S$. aureus SA0620 protein. a Cell lysates (Cells) and TCA-precipitated growth medium (Medium) of L. lactis PA1001 expressing $\mathrm{His}_{6}$-SA0620 (4110), $\mathrm{His}_{6}$-TEV-SA0620 (4111) or SA0620-His 6 (4210) were analysed by Western blotting using anti-His $_{6}$ antibodies. The black arrowhead indicates a potential precursor form of SA0620, the grey arrowhead indicates the mature-sized SA0620 protein and the white arrowhead indicates a degradation product. b The His $_{6}$-SA0620 (4110) was purified form the disrupted cells in the presence of $6 \mathrm{M}$ urea. The start material (S), flow-through fraction $(\mathrm{F})$, wash fractions (W) and elution fractions (E) were analysed by LDS-PAGE and separated proteins were detected by silver staining. The position of His $_{6}$-SA0620 is indicated by an arrow and a co-purified degradation product of this protein is marked $(*)$. The positions of Mw marker proteins are indicated

Upon incubation in the presence of the TEV protease, an additional protein band with an apparent $\mathrm{Mw}$ of $\sim 10 \mathrm{kDa}$ was detectable. This is in agreement with the predicted mass reduction of the His $_{6}$-TEV-FtsL fusion by $\sim 1.7 \mathrm{kDa}$ upon cleavage at the TEV site. The cleavage product was not detected in the control sample, solely TurboTEV protease, indicating the product is $\mathrm{His}_{6}$-TEV-FtsL derived (Fig. 3). Together, these findings show that efficient extracellular protein production can be achieved with pNG4111 and that the His $_{6}$-tag can be removed from the secreted fusion product by cleavage with the TEV protease.

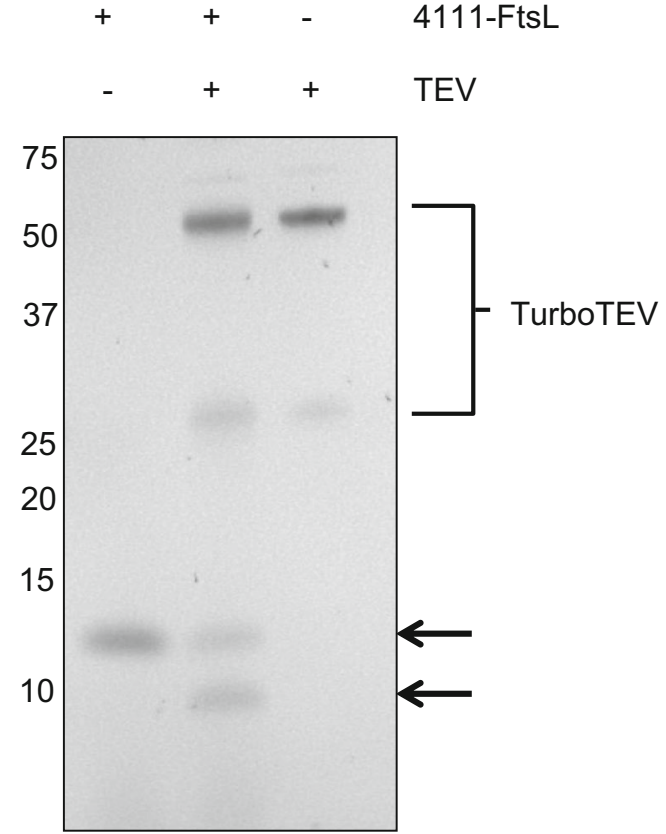

Fig. 3 TEV cleavage of $\mathrm{His}_{6}$-FtsL. Production of the $\mathrm{His}_{6}$-TEV-FtsL protein by L. lactis PA1001 pNG4111-ftsL was induced overnight with nisin. Growth medium containing $\mathrm{His}_{6}$-TEV-FtsL was dialysed against PBS and then the TurboTEV protease $(52 \mathrm{kDa})$ was added. Fractions with or without TurboTEV were separated by LDS-PAGE and stained with SimplyBlue. The positions of Mw marker proteins are indicated

\section{Functional expression of ClfB in $L$. lactis}

To assess whether pNG4110, pNG4111 and pNG4210 facilitate the expression of proteinaceous antigens in L. lactis that are covalently bound to the cell surface of $S$. aureus, the ClfB protein was used. Specifically, the $c l f B$ gene was introduced into the pNG expression vectors without the $3^{\prime}$ sequences that encode the LPxTG motif for sortase recognition and cleavage and the C-terminal transmembrane domain. Furthermore, the original signal peptide of ClfB was replaced with the Usp45 signal peptide. Remarkably, clumping of ClfB-expressing L. lactis strains was detectable (Fig. 4a) in cultures upon overnight induction with nisin. Interestingly, this clumping phenotype was not observed for control cells not expressing ClfB, which suggests that ClfB lacking the LPxTG motif still associates to the cell surface. To verify ClfB production and possible secretion, the cells were separated from the growth medium and both fractions were analysed by LDS-PAGE. Gels were then either stained with SimplyBlue (Fig. 4b) or used for Western blotting and immunodetection using anti-His ${ }_{6}$ antibodies (Fig. 4c). His $_{6}$-tagged proteins were detectable both in the cellular and growth medium fractions (Fig. 4b, c) indicating $\mathrm{ClfB}$ was efficiently expressed from all three vectors (pNG4110, pNG4111 and pNG4210). Notably, several degradation products of the $\mathrm{C}$-terminally $\mathrm{His}_{6}$-tagged $\mathrm{ClfB}$ were detectable in the cell and growth medium fractions, while this 
a

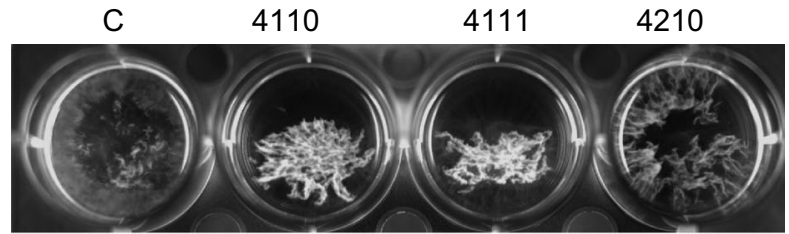

b

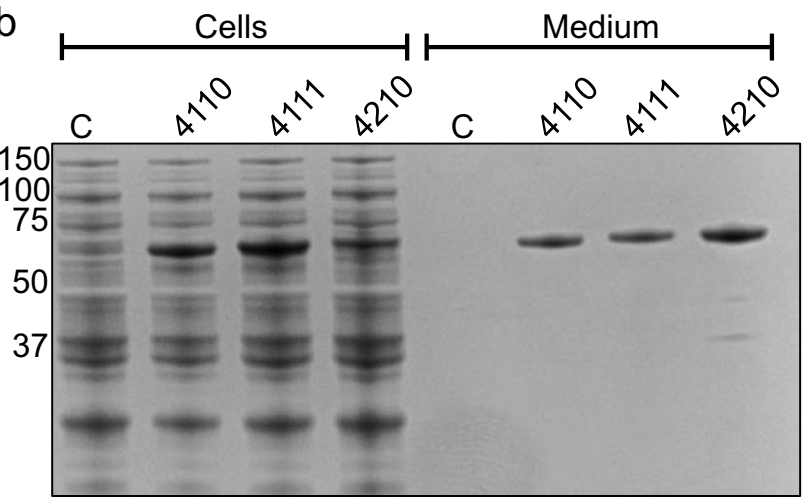

C

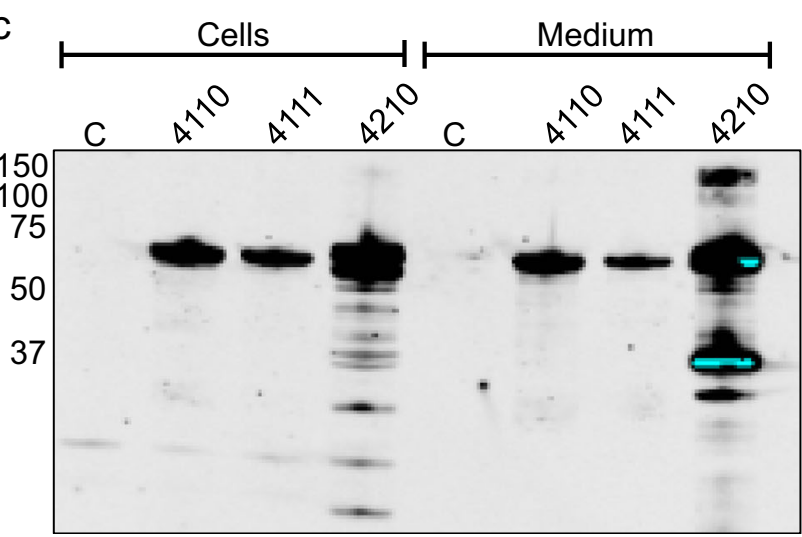

Fig. 4 Functional expression of the $S$. aureus ClfB protein in L. lactis. a Clumping of $L$. lactis PA1001 cells producing $\mathrm{His}_{6}-\mathrm{ClfB}$ (4110), $\mathrm{His}_{6}$ TEV-ClfB (4111) or ClfB-His ${ }_{6}$ (4210) upon overnight induction with nisin. No clumping was observed in the absence of nisin, as shown under (C) for a non-induced control culture of L. lactis PA1001 harbouring pNG4110-clfB. b and $\mathbf{c}$ Cell and growth medium fractions of L. lactis PA1001 producing $\mathrm{His}_{6}$-ClfB (4110), $\mathrm{His}_{6}$-TEV-ClfB (4111) or ClfB-His ${ }_{6}$ (4210) were analysed by LDS-PAGE. Gels were either stained with SimplyBlue SafeStain (b) or used for Western blotting (c) with anti-histidine antibodies. As a control, non-induced L. lactis PA1001 pNG4110-clfB was included in the analysis (C). The positions of Mw marker proteins are indicated

was not the case for the $\mathrm{N}$-terminally $\mathrm{His}_{6}$-tagged forms of ClfB. This suggests that $\mathrm{C}$-terminal $\mathrm{His}_{6}$-tagging makes $\mathrm{ClfB}$ more prone to degradation by as yet unknown proteases of L. lactis. Furthermore, the results shown in Fig. 4 suggest that the location of the $\mathrm{His}_{6}$-tag may influence ClfB-mediated clumping of $L$. lactis cells, since cells expressing ClfB-His ${ }_{6}$ from pNG4210 showed a milder clumping phenotype than cells expressing $\mathrm{His}_{6}-\mathrm{ClfB}$ or $\mathrm{His}_{6}-\mathrm{TEV}-\mathrm{Clfb}$ from pNG4110 or pNG4111, respectively. Whether this relates to differences in the produced amounts of $\mathrm{His}_{6}$-tagged ClfB is difficult to say since the position of the $\mathrm{His}_{6}$-tag seems to influence either the efficiency of SimplyBlue protein staining or of immunodetection with $\mathrm{His}_{6}$-specific antibodies.

\section{Peptidoglycan cleavage activity of SA2100}

To investigate whether non-covalently cell wall-bound proteins of $S$. aureus can be produced in L. lactis using pNG4110, pNG4111 and/or pNG4210, the gene encoding the $S$. aureus SA2100 protein was cloned in these vectors. In the process, the native signal sequence of SA2100 was replaced with the Usp45 signal sequence. As shown in Fig. 5, cell-associated and secreted mature forms of SA2100 were only detectable by expression from pNG4110 or pNG4111, i.e. with $\mathrm{N}$-terminal $\mathrm{His}_{6}$-tags, and not when expressed from the pNG4210 vector that encodes the C-terminally $\mathrm{His}_{6}$ -
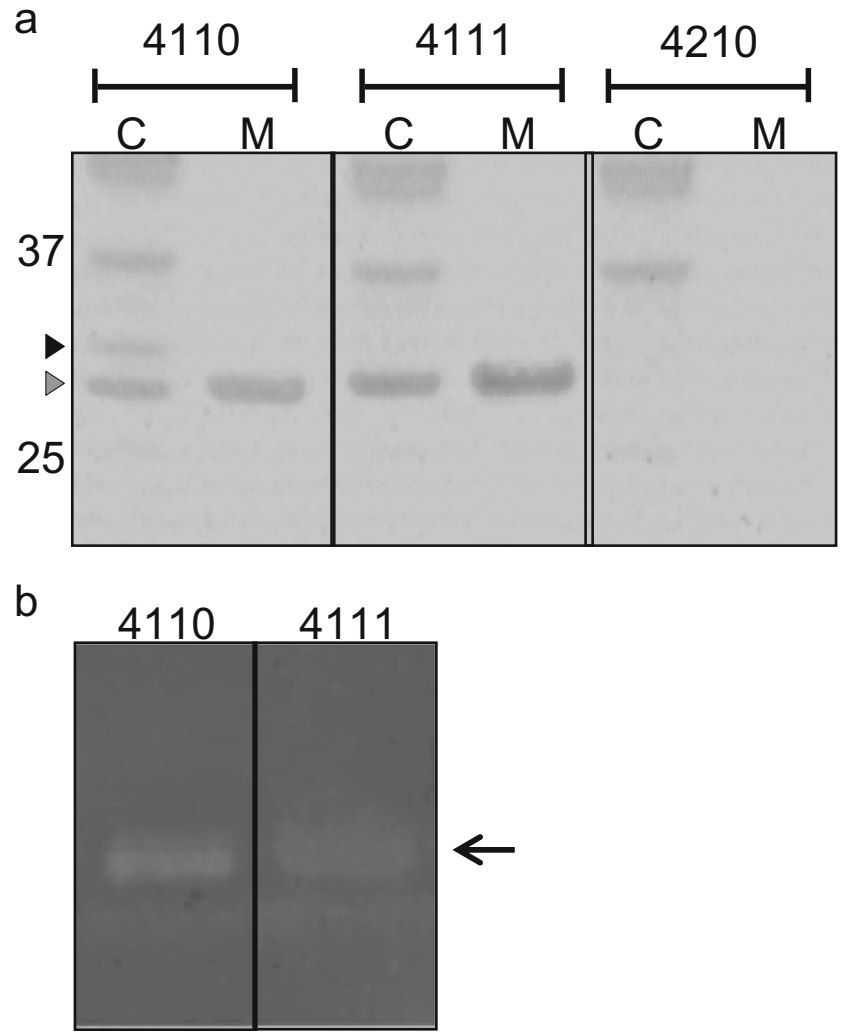

Fig. 5 Functional expression of the $S$. aureus SA2100 protein in L. lactis. a Cells (C) and growth medium (M) fractions of L. lactis PA1001 producing $\mathrm{His}_{6}$-SA2100 (4110), His ${ }_{6}$-TEV-SA2100 (4111) or SA2100$\mathrm{His}_{6}$ (4210) were analysed by LDS-PAGE and stained with SimplyBlue SafeStain. The black arrowhead indicates a potential precursor form of His $_{6}$-SA2100, and the grey arrowhead indicates matured SA2100. The positions of $\mathrm{Mw}$ marker proteins are indicated. $\mathbf{b}$ The cell wall hydrolyzing activity of $\mathrm{His}_{6}$-SA2100 (4110) and $\mathrm{His}_{6}$-TEV-SA2100 (4111) was analysed by zymography upon SDS-PAGE in gels containing M. lysodeikticus cell wall extract. Upon electrophoresis and renaturation of separated proteins, the gel was stained with methylene blue as described in the "Materials and methods" section. A zone of cell wall-degrading activity, which corresponds to the position of mature SA2 100 in the gel upon electrophoresis is indicated with an arrow 
tagged protein. Furthermore, a precursor from of $\mathrm{His}_{6}{ }^{-}$ SA2100 was detectable in cells expressing this protein from pNG4110. Together, these observations support the view that the location of the His $_{6}$-tag can be critical for effective protein production in L. lactis.

Notably, SA2100 is homologous to the autolysin E protein of $S$. aureus and contains a C-terminal domain with similarity to the so-called lysozyme subfamily 2 (LYZ2, smart00047; see the CCD database of NCBI at http://www.ncbi.nlm.nih. gov/Structure/cdd/cdd.shtml). The latter protein family has a peptidoglycan-hydrolyzing activity that is comparable to muramidase activity (Buist et al. 1995). To investigate whether the heterologously expressed and secreted form of SA2100 displays such an activity, a zymogram assay for the degradation of cell wall fragments from M. lysodeikticus was employed. As shown by zymographic analysis, the purified His $_{6}$-SA2100 and His 6 -TEV-SA2100 were both capable of degrading cell wall fragments of M. lysodeikticus (Fig. 5b), which demonstrates that SA2100 is indeed a cell walldegrading enzyme.

\section{Expression of the Atl pro-peptide in L. lactis}

In a recent study, the $\mathrm{N}$-terminal pro-peptide of the bifunctional autolysin Atl of $S$. aureus is reported to be recognized by antibodies in the plasma of patients with the genetic blistering disease epidermolysis bullosa (van den Berg et al. 2015). This intriguing finding initiated an effort to express the pro-Atl (amino acids 29-199) in L. lactis using the three vectors, pNG4110, pNG4111 and pNG4210. As shown in Fig. 6a, the N-terminally $\mathrm{His}_{6}$-tagged pro-Atl as expressed from pNG4110 and pNG4111 was efficiently produced and secreted (Fig. 6a). In fact, most of these His $_{6}$-tagged forms of proAtl were detected in the growth medium from which they were readily purified by metal affinity chromatography (Fig. 6b). Compared to the N-terminally $\mathrm{His}_{6}$-tagged proAtl, only a minute amount of C-terminally $\mathrm{His}_{6}$-tagged proAtl as expressed from pNG4210 was detectable by Western blotting (Fig. 6a).

\section{Secretion of phosphorylated IsdB by $L$. lactis}

Recent studies by Basell et al. have shown that residues Tyr440 or Tyr444 of the covalently cell wall-attached IsdB protein of S. aureus are phosphorylated (Basell et al. 2014). To determine whether IsdB produced and secreted by L. lactis PA1001 is also phosphorylated, a $3^{\prime}$-truncated $i s d B$ gene lacking the sequences encoding the sortase recognition site was expressed from pNG4110 and pNG4111. As shown in Fig. 7, the N-terminally His $_{6}$-tagged forms of IsdB were efficiently produced by L. lactis, and in fact, most of the protein is secreted into the growth medium. Importantly, phosphorylated $\mathrm{His}_{6}$-tagged IsdB was clearly detectable by gel staining with
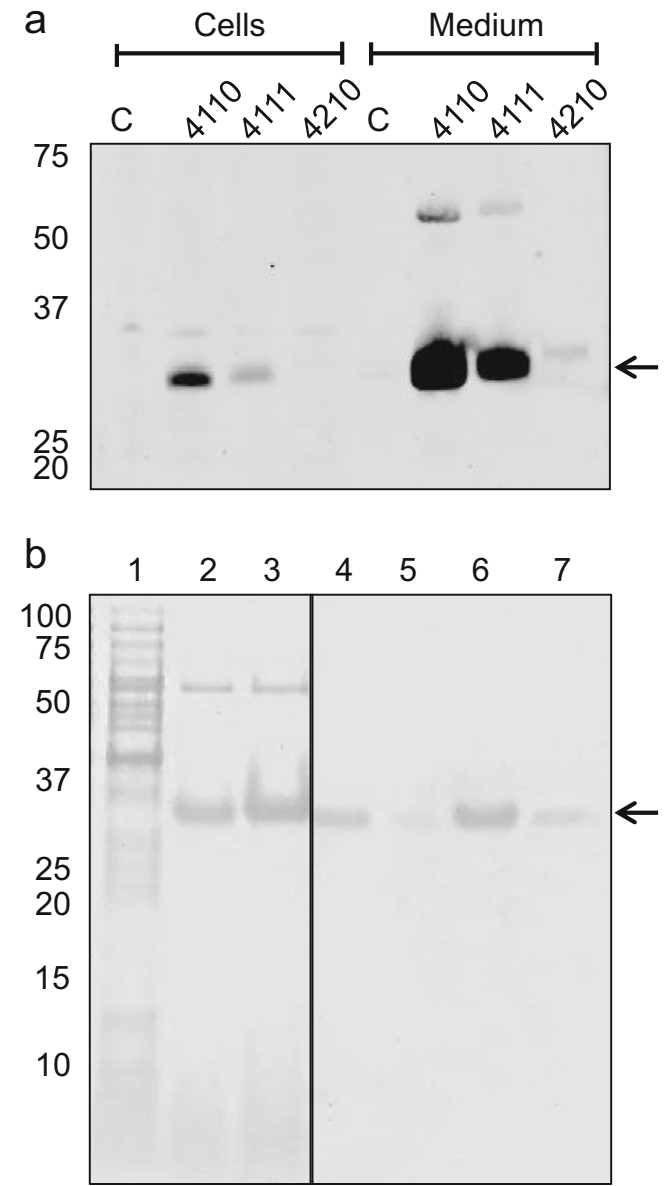

Fig. 6 Production and purification of the $S$. aureus pro-Atl pro-peptide. a Cells and growth medium fractions of L. lactis PA1001 producing $\mathrm{His}_{6}{ }^{-}$ Pro-Atl (4110), His 6 -TEV-Pro-Atl (4111) or Pro-Atl-His 6 (4210) were analysed by LDS-PAGE and subsequent Western blotting using anti$\mathrm{His}_{6}$ antibodies. As a control, non-induced L. lactis PA1001 pNG4110pro-atl was included in the analysis (C). Pro-Atl is indicated with an arrow. b Purification of $\mathrm{His}_{6}$-Pro-Atl and $\mathrm{His}_{6}$-TEV-Pro-Atl from the supernatant of cells that were induced with nisin overnight. The LDSPAGE shows (1) induced cells producing His ${ }_{6}$-Pro-Atl, (2) the culture supernatant fraction of cells producing His $_{6}$-Pro-Atl, (3) the culture supernatant fraction of cells producing His $_{6}$-TEV-Pro-Atl, (4/5) the first two elution fractions of $\mathrm{His}_{6}$-Pro-Atl upon metal affinity chromatography and $(6 / 7)$ the first two elution fractions of His $_{6}$-TEV-Pro-Atl upon metal affinity chromatography. The position of $\mathrm{His}_{6}$-tagged Pro-Atl is marked with an arrow, and the positions of Mw marker proteins are indicated

the Pro-Q ${ }^{\circledR}$ Diamond Phosphoprotein Gel Stain, showing L. lactis facilitates this post-translational modification. Whether the cytoplasmic forms of $\mathrm{His}_{6}$-IsdB and $\mathrm{His}_{6}$-TEVIsdB as observed by Western blotting are also phosphorylated is presently unclear due to limited sensitivity of the Pro-Q staining in these extracts.

To pinpoint the site of IsdB phosphorylation in L. lactis, the secreted $\mathrm{His}_{6}$-TEV-IsdB was purified by metal affinity chromatography and applied to an LDS-PAA gel. The His ${ }_{6}$-TEVIsdB band was subsequently excised from the gel, destained, washed and cleaved overnight with trypsin. Liberated peptides were analysed by MS/MS, which showed that His $_{6-}$ 
Fig. 7 Extracellular production of phosphorylated $S$. aureus IsdB in L. lactis. a Cytosolic (C) and growth medium $(\mathrm{M})$ fractions of L. lactis PA1001 producing $\mathrm{His}_{6-}$ IsdB (4110) and His $_{6}$-TEV-IsdB (4111) were analysed by LDSPAGE and stained with SimplyBlue SafeStain (SB) or Pro-Q Diamond staining (Pro-Q). As a control, Western blotting was performed, using anti-His 6 antibodies ( $\alpha$-His). The arrow marks the position of mature IsdB, and the positions of $\mathrm{Mw}$ marker proteins are indicated
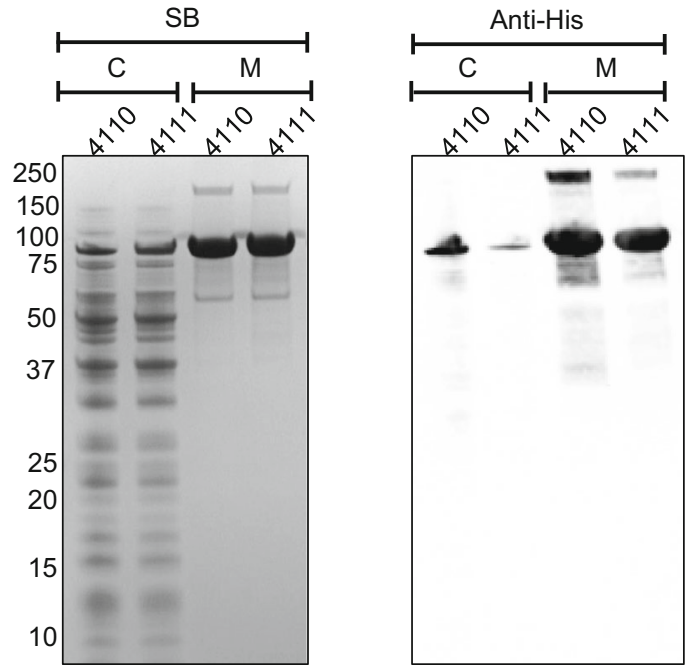

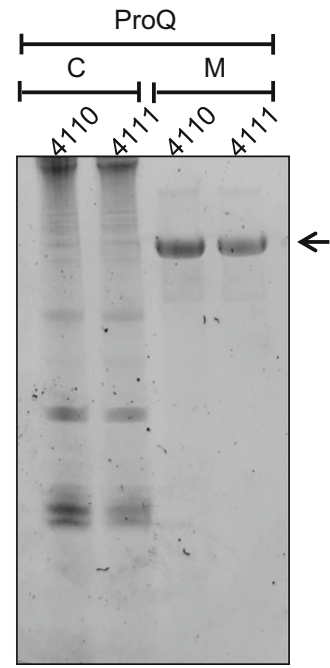

TEV-IsdB was phosphorylated on the Tyr311( ${ }^{*}$ ) residue in the peptide KYMVMETTNDDY*WKDFMVEGQR (Supplementary Fig. S1). The same Tyr residue was also shown to be phosphorylated when TCA-precipitated His $_{6}$ TEV-IsdB from the culture supernatant of L. lactis PA1001 containing pNG4111-IsdB was used for the MS/MS analysis.

\section{Discussion}

In the present study we describe a set of three cloning vectors for heterologous protein expression in L. lactis. These vectors enable easy exchange of the gene of interest for expression of protein variants with (i) a N-terminal $\mathrm{His}_{6}$-tag, (ii) a Cterminal $\mathrm{His}_{6}$-tag and (iii) a TEV protease cleavable $\mathrm{C}$ terminal $\mathrm{His}_{6}$ protein. Examples of the successful use of the three vectors are presented for expression of six extracytoplasmic proteins from $S$. aureus, two of which were subsequently purified in one step by metal affinity chromatography.

Importantly, the position of the His $_{6}$-tag purification label, either at the $\mathrm{N}$ - or the $\mathrm{C}$-terminus, can have a major impact on the production level of $S$. aureus originated proteins expressed in L. lactis. This was particularly evident for SA0620, SA2100 and pro-Atl, which were only detectable when expressed as Nterminal $\mathrm{His}_{6}$-tagged protein. In contrast, no effect of the $\mathrm{His}_{6}$ tag position was observed for the production of FtsL, ClfB and IsdB (data not shown for FtsL and IsdB). The reason(s) for the negative impact of a $\mathrm{C}$-terminal $\mathrm{His}_{6}$-tag on the production of SA0620, SA2100 and pro-Atl is presently not clear. For the SA0620 protein, the tag appears to interfere with the protein stability/folding as indicated by the presence of a degradation product. Similar degradation products are observed for the Cterminally $\mathrm{His}_{6}$-tagged $\mathrm{ClfB}$, whereas these are not observed for the N-terminally $\mathrm{His}_{6}$-tagged ClfB. Similarly, the TEV cleavage site as encoded by pNG4111 may influence the protein production level. This was most evident for SA0620, although effects of the TEV cleavage site on the levels of detected product were also observed for ClfB and pro-Atl. However, for the latter two proteins, it is presently not entirely clear whether the TEV site interfered with protein production per se or with the immunodetection of the $\mathrm{His}_{6}$-tag with antiHis $_{6}$-tag antibodies. The latter idea would be supported by the experiments on $\mathrm{ClfB}$ production, where there was a discrepancy between the ClfB levels detected by SimplyBlue gel staining and immunodetection.

With the exception of SA0620, all S. aureus proteins expressed in L. lactis were secreted into the growth medium with the help of the vector-encoded Usp45 signal peptide. The cause of the deviating behaviour of SA0620, which is part of the core exoproteome of $S$. aureus (Sibbald et al. 2006; Ziebandt et al. 2010), is unknown. Apparently, this protein has a particular unidentified feature that interferes with its secretion in L. lactis. This could, for example, relate to its targeting to the Sec secretion machinery, pre-translocational control of folding by chaperones or efficient posttranslocational folding by dedicated folding catalysts that could be present in S. aureus but absent from L. lactis.(Sarvas et al. 2004; Bolhuis et al. 1999; Tjalsma et al. 2004)

The expression host strain used for the present studies was L. lactis PA1001, which lacks the major lactococcal proteases PrtP and HtrA (Poquet et al. 2000; Liu et al. 2010). Despite the absence of these two proteases, our results show that proteolysis of expressed proteins can still occur. This focuses attention on the remaining proteases that could be responsible for this unwanted effect. Conceivably, the responsible protease could be located in the cytoplasm (e.g. ClpP; Frees et al. 2001), the membrane (e.g. FtsH or a RseP-like protease; Dalbey et al. 2012) or an as yet unidentified protease in the cell wall. The elimination of this remnant protease activity could be beneficial for further production strain improvement, 
similar to what was shown for heterologous protein production in $B$. subtilis where the deletion of multiple protease genes resulted in large improvements in the production of heterologous proteins (Pohl et al. 2013; Krishnappa et al. 2014).

Lastly, our analysis of the production of S. aureus IsdB in $L$. lactis shows that this heterologous expression host does phosphorylate the IsdB protein as is the case in $S$. aureus (Basell et al. 2014). However, while in S. aureus either Tyr440 or Tyr444 are phosphorylated, the IsdB protein expressed in L. lactis was found to be phosphorylated on Tyr311. At present, the molecular basis for this apparently different choice of phosphorylation sites in $S$. aureus and L. lactis is not clear. One possible reason for the different results could be that the sample preparation was performed differently. While Basell et al. (2014) applied a gel-free proteomics analysis where phosphopeptides were enriched with $\mathrm{TiO}_{2}$, in the present analyses the IsdB protein was extracted from gel slices. Another perhaps more plausible reason could be that we expressed in L. lactis a 3'-truncated isdB gene lacking the sequences encoding the sortase recognition site and encoding a TEV protease cleavable N-terminal His $_{6}$-tag. This may have resulted in an aberrant presentation of IsdB to the as yet unknown kinase responsible for phosphorylation of this protein. In contrast, the study in $S$. aureus addressed the authentic IsdB protein synthesized with the sortase cleavage site and, therefore, covalently anchored to the cell wall. A third possibility would be that the kinases responsible for IsdB phosphorylation in S. aureus and L. lactis have somewhat different specificities. A careful comparative analysis of the mechanisms of IsdB phosphorylation in S. aureus and L. lactis may pinpoint possible hostspecific differences.

In conclusion, based on our present findings, we are confident that the newly developed vectors combined with the L. lactis expression host PA1001 have the potential to become very useful tools for the extracytoplasmic production and purification of bacterial antigens. Such a tool facilitates structural and functional studies on previously hard-to-produce proteins and may provide a starting point for vaccine development.

Acknowledgments We like to thank Sabrina Jacobs, Ilona Schepel and Alain Dekker for their experimental contribution.

Funding This research was supported by the Top Institute Pharma projects T4-213 and T4-502.

Conflict of interest The authors declare that they have no competing interests.

Compliance with ethical standards This article does not contain any studies with human participants or animals performed by any of the authors.
Open Access This article is distributed under the terms of the Creative Commons Attribution 4.0 International License (http:// creativecommons.org/licenses/by/4.0/), which permits unrestricted use, distribution, and reproduction in any medium, provided you give appropriate credit to the original author(s) and the source, provide a link to the Creative Commons license, and indicate if changes were made.

\section{References}

Arnau J, Lauritzen C, Petersen GE, Pedersen J (2011) Reprint of: Current strategies for the use of affinity tags and tag removal for the purification of recombinant proteins. Protein Expr Purif

Bardoel BW, Van Kessel KPM, Van Strijp JAG, Milder FJ (2012) Inhibition of Pseudomonas aeruginosa virulence: characterization of the AprA-AprI interface and species selectivity. J Mol Biol 415: $573-583$

Basell K, Otto A, Junker S, Zuhlke D, Rappen GM, Schmidt S, Hentschker C, Macek B, Ohlsen K, Hecker M, Becher D (2014) The phosphoproteome and its physiological dynamics in Staphylococcus aureus. Int J Med Microbiol 304:121-132

Bolhuis A, Tjalsma H, Smith HE, de Jong A, Meima R, Venema G, Bron S, van Dijl JM (1999) Evaluation of bottlenecks in the late stages of protein secretion in Bacillus subtilis. Appl Environ Microbiol 65: 2934-2941

Bonn F, Bartel J, Buttner K, Hecker M, Otto A, Becher D (2014) Picking vanished proteins from the void: how to collect and ship/share extremely dilute proteins in a reproducible and highly efficient manner. Anal Chem 86:7421-7427

Bosma T, Kanninga R, Neef J, Audouy SAL, Van Roosmalen ML, Steen A, Buist G, Kok J, Kuipers OP, Robillard G, Leenhouts K (2006) Novel surface display system for proteins on non-genetically modified gram positive bacteria. Appl Environ Microbiol 72:880-889

Braun P, Gerritse G, van Dijl JM, Quax WJ (1999) Improving protein secretion by engineering components of the bacterial translocation machinery. Curr Opin Biotechnol 10:376-381

Buist G, Kok J, Leenhouts KJ, Dabrowska M, Venema G, Haandrikman AJ (1995) Molecular cloning and nucleotide sequence of the gene encoding the major peptidoglycan hydrolase of Lactococcus lactis, a muramidase needed for cell separation. J Bacteriol 177:1554-1563

Buist G, Karsens H, Nauta A, Van Sinderen D, Venema G, Kok J (1997) Autolysis of Lactococcus lactis caused by induced overproduction of its major autolysin, AcmA. Appl Environ Microbiol 63:27222728

Chen R (2012) Bacterial expression systems for recombinant protein production: E. coli and beyond. Biotechnol Adv 30:1102-1107

Cortes-Perez NG, Poquet I, Oliveria MN, Gratadoux JJ, Madsen SM, Miyoshi A, Corthier G, Azevedo V, Langella P, BermudezHumaran LG (2006) Construction and characterization of a Lactococcus lactis strain deficient in intracellular ClpP and extracellular HtrA proteases. Microbiology 152:2611-2618

Dalbey RE, Wang P, van Dijl JM (2012) Membrane proteases in the bacterial protein secretion and quality control pathway. Microbiol Mol Biol Rev 76:311-330

De Ruyter PGGA, Kuipers OP, De Vos WM (1996) Controlled gene expression systems for Lactococcus lactis with the food-grade inducer nisin. Appl Environ Microbiol 62:3662-3667

Duthie ES, Lorenz LL (1952) Staphylococcal coagulase; mode of action and antigenicity. J Gen Microbiol 6:95-107

Frees D, Varmanen P, Ingmer H (2001) Inactivation of a gene that is highly conserved in Gram-positive bacteria stimulates degradation of non-native proteins and concomitantly increases stress tolerance in Lactococcus lactis. Mol Microbiol 41:93-103 
Jones C, Patel A, Griffin S, Martin J, Young P, O’Donnell K, Silverman C, Porter T, Chaiken I (1995) Current trends in molecular recognition and bioseparation. J Chromatogr A 707:3-22

Kreiswirth BN, Löfdahl S, Betley MJ, O'Reilly M, Schlievert PM, Bergdoll MS, Novick RP (1983) The toxic shock syndrome exotoxin structural gene is not detectably transmitted by a prophage. Nature 305:709-712

Krishnappa L, Dreisbach A, Otto A, Goosens VJ, Cranenburgh R, Harwood CR, Becher D, Van Dijl JM (2013) Extracytoplasmic proteases determining the cleavage and release of secreted proteins, lipoproteins, and membrane proteins in Bacillus subtilis. J Proteome Res 12:4101-4110

Krishnappa L, Monteferrante CG, Neef J, Dreisbach A, Van Dijl JM (2014) Degradation of extracytoplasmic catalysts for protein folding in Bacillus subtilis. Appl Environ Microbiol 80:1463-1468

Kuipers OP, Beerthuyzen MM, Siezen RJ, De Vos WM (1993) Characterization of the nisin gene cluster nisABTCIPR of Lactococcus lactis. Requirement of expression of the nis $A$ and nisI genes for development of immunity. Eur J Biochem 216:281-291

Kuipers OP, De Ruyter PGGA, Kleerebezem M, De Vos WM (1997) Controlled overproduction of proteins by lactic acid bacteria. Trends Biotechnol 15:135-140

Kuroda M, Ohta T, Uchiyama I, Baba T, Yuzawa H, Kobayashi I, Cui L, Oguchi A, Aoki K, Nagai Y, Lian J, Ito T, Kanamori M, Matsumaru H, Maruyama A, Murakami H, Hosoyama A, Mizutani-Ui Y, Takahashi NK, Sawano T, Inoue R, Kaito C, Sekimizu K, Hirakawa H, Kuhara S, Goto S, Yabuzaki J, Kanehisa M, Yamashita A, Oshima K, Furuya K, Yoshino C, Shiba T, Hattori M, Ogasawara N, Hayashi H, Hiramatsu K (2001) Whole genome sequencing of meticillin-resistant Staphylococcus aureus. Lancet 357:1225-1240

Leenhouts KJ, Venema G (1993) Lactococcal plasmid vectors. In: Hardy KG (ed) Plasmids, a practical approach. Oxford University Press, Oxford, pp 65-94

Li W, Zhou X, Lu P (2004) Bottlenecks in the expression and secretion of heterologous proteins in Bacillus subtilis. Res Microbiol 155:605-610

Liu M, Bayjanov JR, Renckens B, Nauta A, Siezen RJ (2010) The proteolytic system of lactic acid bacteria revisited: a genomic comparison. BMC Genomics 11:36-2164

McDougal LK, Steward CD, Killgore GE, Chaitram JM, McAllister SK, Tenover FC (2003) Pulsed-field gel electrophoresis typing of oxacillin-resistant Staphylococcus aureus isolates from the United States: establishing a national database. J Clin Microbiol 41:51135120

Mierau IKM (2005) 10 Years of the nisin controlled gene expression system (NICE) in Lactococcus lactis. Appl Microbiol Biotechnol 68:705-717

Miyoshi A, Poquet I, Azevedo V, Commissaire J, Bermudez-Humaran LG, Domakova E, Le Loir Y, Oliveira SC, Grusse A, Langella P (2002) Controlled production of stable heterologous proteins in Lactococcus lactis. Appl Environ Microbiol 68:3141-3146

Morello E, Bermudez-Humaran LG, Llull D, Sole V, Miraglio N, Langella P, Poquet I (2008) Lactococcus lactis, an efficient cell factory for recombinant protein production and secretion. J Mol Microbiol Biotechnol 14:48-58

Neef J, Koedijk DG, Bosma T, van Dijl JM, Buist G (2014) Efficient production of secreted staphylococcal antigens in a non-lysing and proteolytically reduced Lactococcus lactis strain. Appl Microbiol Biotechnol 98:10131-10141

Pel MJ, van Dijken AJ, Bardoel BW, Seidl MF, van der Ent S, van Strijp JA, Pieterse CM (2014) Pseudomonas syringae evades host immunity by degrading flagellin monomers with alkaline protease AprA. Mol Plant Microbe Interact 27:603-610

Petsch D, Anspach FB (2000) Endotoxin removal from protein solutions. J Biotechnol 76:97-119

Pohl S, Bhavsar G, Hulme J, Bloor AE, Misirli G, Leckenby MW, Radford DS, Smith W, Wipat A, Williamson ED, Harwood CR, Cranenburgh RM (2013) Proteomic analysis of Bacillus subtilis strains engineered for improved production of heterologous proteins. Proteomics 13:3298-3308

Poquet I, Saint V, Seznec E, Simoes N, Bolotin A, Gruss A (2000) HtrA is the unique surface housekeeping protease in Lactococcus lactis and is required for natural protein processing. Mol Microbiol 35:10421051

Sarvas M, Harwood CR, Bron S, Van Dijl JM (2004) Post-translocational folding of secretory proteins in Gram-positive bacteria. Biochim Biophys Acta 1694:311-327

Sibbald MJJB, Ziebandt AK, Engelmann S, Hecker M, De Jong A, Hamsen HJM, Raangs GC, Stokroos I, Arends JP, Dubois JYF, Van Dijl JM (2006) Mapping the pathway to staphylococcal pathogenesis by comparative secretomics. Microbiol Mol Biol Rev 70: $755-788$

Terpe K (2003) Overview of tag protein fusions: from molecular and biochemical fundamentals to commercial systems. Appl Microbiol Biotechnol 60:523-533

Terpe K (2006) Overview of bacterial expression system for heterologous protein production from molecular and biochemical fundamentals to commercial systems. Appl Microbiol Biotechnol 72:211-222

Tjalsma H, Koetje EJ, Kiewiet R, Kuipers OP, Kolkman M, Van der Laan J, Daskin R, Ferrari E, Bron S (2004) Engineering of quorumsensing systems for improved production of alkaline protease by Bacillus subtilis. J Appl Microbiol 96:569-578

van den Berg S, Koedijk DG, Back JW, Neef J, Dreisbach A, van Dijl JM, Bakker-Woudenberg IA, Buist G (2015) Active immunization with an octa-valent Staphylococcus aureus antigen mixture in models of $S$. aureus bacteremia and skin infection in mice. PLoS One 10 , $\mathrm{e} 0116847$

Westers L, Westers H, Quax WJ (2004) Bacillus subtilis as cell factory for pharmaceutical proteins: a biotechnological approach to optimize the host organism. Biochim Biophys Acta 1694:299-310

Woestenenk EA, Hammarstrom M, van den Berg S, Hard T, Berglund H (2004) His tag effect on solubility of human proteins produced in Escherichia coli: a comparison between four expression vectors. J Struct Funct Genomics 5:217-229

Zerbs S, Frank AM, Collart FR (2009) Bacterial systems for production of heterologous proteins. Methods Enzymol 463:149-168

Zhou XX, Li WF, Ma GX, Pan YJ (2006) The nisin-controlled gene expression system: construction, application and improvements. Biotechnol Adv 24:285-295

Ziebandt AK, Kusch H, Degner M, Jaglitz S, Sibbald MJ, Arends JP, Chlebowicz MA, Albrecht D, Pantucek R, Doskar J, Ziebuhr W, Broker BM, Hecker M, Van Dijl JM, Engelmann S (2010) Proteomics uncovers extreme heterogeneity in the Staphylococcus aureus exoproteome due to genomic plasticity and variant gene regulation. Proteomics 10:1634-1644 